\title{
Haploidentical Hematopoietic Cell Transplantation
}

National Cancer Institute

\section{Source}

National Cancer Institute. Haploidentical Hematopoietic Cell Transplantation. NCI

Thesaurus. Code C138187.

A clinical treatment in which hematopoietic stem cells are transferred from a HLA halfmatched donor to a recipient. 